\title{
Physiological quality of castor bean seeds originating from different racemes in the plant ${ }^{1}$
}

\author{
Andréia Márcia Santos de Souza David²*, Eduardo Fontes Araújo ${ }^{3}$, \\ Roberto Fontes Araújo ${ }^{4}$, Maria Aparecida Vilela de Resende 5 , \\ Denise Cunha Fernandes dos Santos Dias ${ }^{3}$, Danúbia Aparecida Costa Nobre ${ }^{6}$
}

\begin{abstract}
The harvesting is one of the most critical phases in castor bean seed production system, once physiological quality of the seeds produced in the different types of racemes in the plant can be affected. The aim of this study was assessing physiological quality of castor bean seeds in function of position of the racemes on plant. Castor bean seeds, cv. IAC-226, harvested separately at distinct periods from primary, secondary, and tertiary racemes, or of mixture of seeds originating from the different types of racemes were used. Soon after harvest, the following determinations were performed: moisture content; 1,000 seeds weight; germination; first count of germination; seedling emergence; emergence speed index; and length and dry matter of seedlings. A completely randomized experimental design was used with four repetitions. Data were subjected to ANOVA and means were compared by Tukey test, at $5 \%$ probability. The seeds from primary racemes present higher weight and vigor as compared to seeds produced on other types of racemes. Seeds originating from secondary and tertiary racemes present post-harvest dormancy, being this event more evident on seeds originating from tertiary racemes.
\end{abstract}

Index terms: Ricinus communis L., harvest, oilseed, germination, vigor.

\section{Qualidade fisiológica de sementes de mamona provenientes de diferentes racemos da planta}

\begin{abstract}
RESUMO - A colheita é uma das fases mais críticas do sistema de produção de sementes de mamona, pois a qualidade fisiológica das sementes produzidas nos diferentes tipos de racemos da planta pode ser afetada. O objetivo nesta pesquisa foi avaliar a qualidade fisiológica de sementes de mamona em função da posição dos racemos na planta. Foram utilizadas sementes de mamona, da cv IAC-226, colhidas separadamente em épocas distintas, dos racemos primários, secundários e terciários, ou da mistura das sementes produzidas nos diferentes tipos de racemos. Após a colheita foram realizadas as seguintes determinações: grau de umidade; peso de 1.000 sementes; germinação; primeira contagem de germinação; emergência de plântulas; índice de velocidade de emergência; e comprimento e matéria seca de plântulas. Foi utilizado o delineamento experimental inteiramente casualizado, com quatro repetições. Os dados foram submetidos à análise de variância e as médias foram comparadas pelo teste Tukey, a $5 \%$ de probabilidade. As sementes dos racemos primários apresentam maior peso e vigor quando comparadas às sementes produzidas nos demais tipos de racemos. As sementes dos racemos secundários e terciários apresentam dormência pós-colheita, sendo esta mais acentuada nas sementes produzidas nos racemos terciários.
\end{abstract}

Termos para indexação: Ricinus communis L., colheita, semente oleaginosa, germinação, vigor.

${ }^{1}$ Submitted on 04/17/2011. Accepted for publication on 01/05/2012. ${ }^{2}$ Universidade Estadual de Montes Claros (UNIMONTES), Caixa Postal 91, 39440-000 - Janaúba, MG, Brasil.

${ }^{3}$ Departamento de Fitotecnia, UFV, 36570-000, Viçosa, MG, Brasil.

${ }^{4}$ Empresa de Pesquisa Agropecuária de Minas Gerais (EPAMIG), 36570-000, Viçosa, MG, Brasil.
${ }^{5}$ Universidade do Estado de Minas Gerais (UEMG), 36500-000 - Ubá, MG, Brasil.

${ }^{6}$ Instituto de Ciências Agrárias, UFMG, Caixa Postal 135, 39404-006 Montes Claros, MG, Brasil.

*Corresponding author < andreia.david@unimontes.br> 


\section{Introduction}

Some important issues should be considered for a profitable biodiesel production, such as: productivity of the oilseed plant that will be grown; the technology used for its cultivation; the production cost; and the commercial use of by-products generated. Castor bean (Ricinus communis L.) is an oilseed plant with large adaptability to different environmental conditions and its seeds possess from $40 \%$ to $60 \%$ oil with large industrial application; and may be regarded as the rawmaterial of future on biodiesel production.

In the semiarid region of Brazil, despite the socioeconomic and environmental advantages of biodiesel production based on castor oil, the productivity of this oilseed plant is still low (Freitas and Fredo, 2005). Therefore, to improve productivity of castor bean crop in that region, further investments are needed in the agronomic research applied to genetic and to quality improvement of this crop seeds.

For guaranteeing quality of the castor bean seeds, the study of optimal harvesting moment is very important, once flowering and fruiting of the racemes are uneven, and the emergence of inflorescence occurs sequentially. In face of this maturation unevenness, doubts are raised about the harvest ideal period: if the harvesting should be split, reaping the racemes when each matures; or at one single time, after maturation of all racemes. Nevertheless, when harvest is performed at inappropriate moment, losses may occur on physiological quality of seeds as much in function of their permanence in field after physiological maturity has been reached, as through the harvesting of immature seeds. The delay on harvest, after the physiological maturity, implies in serious drawbacks determined by the relatively high exposure of the seeds to the less favorable environmental conditions, as the alternation of dry and humid periods that, combined with high temperatures, may cause fall of physiological potential of seeds. These characteristics may influence initial quality of seeds, as well as their storage potential.

According to Machado et al. (2010) the position of fruit on the plant or on inflorescence, or the position of seed in fruit, can also affect quality of seeds due to dormancy. Lago et al. (1979) have emphasized that the castor bean seeds also may present dormancy, whose intensity and persistence depend chiefly on the cultivar and on seed maturation stage at harvest moment, and that this dormancy is more accentuated on the seeds of tertiary racemes.

Hence, the objective of this study was to assess physiological quality of castor bean seeds, originating from different racemes produced on different positions on the plants grown in municipality of Janaúba, northern Minas Gerais state.

\section{Material and Methods}

The field area for production of castor bean seeds was installed at the Experimental Farm of the Universidade Estadual de Montes Claros (Unimontes), in municipality of Janaúba - MG, in January 23rd, 2006. Laboratory analyses were performed in the Seed Testing Laboratory of the Technological Center of North of Minas Gerais (CTNM EPAMIG) also locate in Janaúba.

The Experimental Farm of Unimontes is located in the latitude $15^{\circ} 49^{\prime} 51.5^{\prime \prime} \mathrm{S}$; longitude $43^{\circ} 16^{\prime} 18.2$ ' $\mathrm{W}$; and altitude $540 \mathrm{~m}$. The mean annual precipitation in the region is of approximately $870 \mathrm{~mm}$ and the insolation is of 2,700 hours annually. According to Köppen classification, the climate in this region is classified as Aw - tropical savanna with dry winter. The minimal and maximal temperatures $\left({ }^{\circ} \mathrm{C}\right)$ and relative humidity (\%) recorded during the experiment are presented on Figure 1.

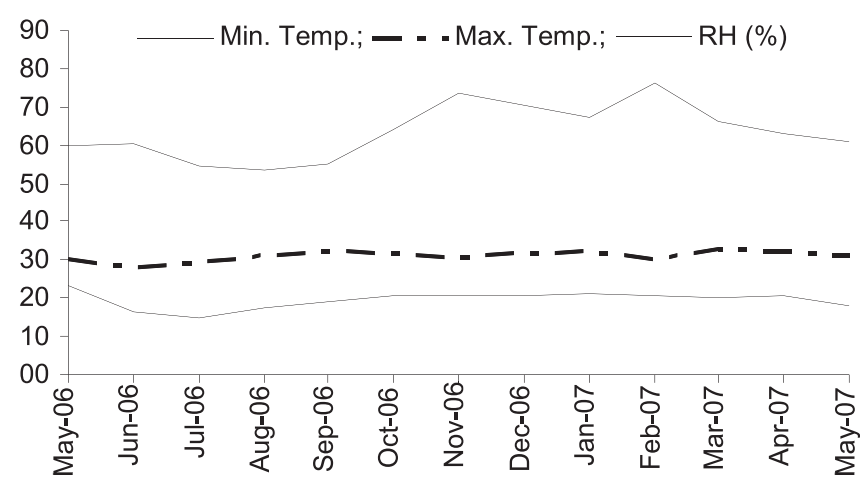

Figure 1. Temperatures minimal and maximal $\left({ }^{\circ} \mathrm{C}\right)$ and relative humidity $(\mathrm{RH})$ recorded at the Meteorological Station of EPAMIG, north of Minas Gerais State, between May, 2006 and May, 2007.

For the experiments, were used seeds of castor bean, cv. IAC-226, which was the first castor bean commercial cultivar with adequate plant height, low branching, with indehiscent fruits, and small seeds, developed by Agronomic Institute of Campinas (IAC) and that presents high potential for production and medium vegetative cycle.

The sowing fertilization was performed according to soil analysis, and following recommendations for the castor bean cultivation (Gonçalves, et al., 2005) using 15, 30, and $80 \mathrm{~kg}$.ha-1 $\mathrm{N}, \mathrm{P}_{2} \mathrm{O}_{5}$, and $\mathrm{K}_{2} \mathrm{O}$, respectively. The cover fertilization was carried out on 44 days after sowing with $30 \mathrm{~kg} \cdot \mathrm{ha}^{-1} \mathrm{~N}$, and the weeding was manually performed.

After sowing, the technical recommendations needed for the ideal development of castor bean crop were adopted, including supplementary irrigation. According to 
recommendations of Mazzani (1983), the sprinkler irrigation system was used, which was initiated at seeding and was extended until approximately 40 days before harvest. The irrigation was performed during one hour per day, totaling a volume of water equivalent to $800 \mathrm{~mm}$ rainfall, which was distributed over a 120 days irrigation period, which comprise almost all cycle of the crop.

The staggered harvesting of racemes was performed at 110,144 , and 178 days after sowing. For this, plants were randomly selected, being the primary racemes harvested at 110 days, the secondary racemes at 144 days and the tertiary racemes at 178 days after sowing. After 178 days, all primary, secondary, and tertiary racemes that had remained on the plants were harvested at same time; this way, the other treatment type used in the experiment (mixture of racemes) was constituted. All types of racemes were collected when circa $100 \%$ of fruits were fully ripe, and the seed moisture content was circa $7.0 \%$.

After harvested, the racemes were taken to laboratory where their fruits were manually removed. Extraction and cleaning of seeds were also performed manually, removing empty seeds as well as impurities. To assess physiological quality of these seeds, several different tests were carried out.

Seed moisture content was determined according to Brasil (2009) by using the oven method, at $105 \pm 3{ }^{\circ} \mathrm{C}$, during $24 \mathrm{~h}$, with two subsamples of approximately $32 \mathrm{~g}$ each, for each of the four replications per treatment. Results were expressed as percentage.

The weight of 1,000 seeds also was determined, using eight subsamples of 100 seeds each per each treatment replication. The seeds were weighed in a balance, with 0.001 $\mathrm{g}$ precision. Variance, standard deviation, and coefficient of variation of the values obtained in weighing were computed following the criteria established by Brasil (2009), and results were expressed in grams.

The germination test was performed with three subsamples of 50 seeds each, per each treatment replication. For that, the seeds of each subsample were evenly distributed on two sheets of Germitest ${ }^{\circledR}$ paper and covered with another sheet previously moistened with distilled water in a volume equivalent to 2.5 times the mass of dry paper. The rolls were then placed into a germinator previously regulated to alternating temperatures of $20^{\circ} \mathrm{C}$ and $30{ }^{\circ} \mathrm{C}$, under constant light. Counts were performed at the seventh and 14th day after sowing (Brasil, 2009) and the results were expressed as a percentage of normal seedlings.

The first count of germination was obtained by counting the percentage of normal seedlings originating from the germination test at seventh day after sowing (Brasil, 2009).
The seedling emergence test was carried out in the laboratory under environmental conditions. Fine and washed sand was sterilized in an oven at $200{ }^{\circ} \mathrm{C}$, during $2 \mathrm{~h}$, and then this substrate was used to fill plastic trays, into which the seeds were sown in rows at $3 \mathrm{~cm}$ deep. Immediately after sowing, substrate was moistened until a $60 \%$ water retention capacity (Brasil, 2009). Three subsamples of 50 seeds each were used for each replication of treatments, and results were obtained by counting number of normal seedlings that have emerged at 14th day after sowing. The number of seedling was daily assessed by counting the number of emerged seedlings and that were presenting visible cotyledonal hook until stabilization of germination process; what stopped occurring 10 days after sowing. The emergence speed index was determined according to equation proposed by Maguire (1962).

At end of seedling emergence test, the length of the normal seedlings was determined using a ruler graduated in millimeters; and afterwards their dry weight was also determined. For this, the seedling of each replication were placed into Kraft paper bags and taken to dry into air circulating drying oven, at constant temperature of $65^{\circ} \mathrm{C}$, during $72 \mathrm{~h}$, and results were expressed in mg.seedling ${ }^{-1}$.

A completely randomized experimental design was used with four replications per treatment. Results were subjected to ANOVA and to $\mathrm{F}$ test, at $5 \%$ probability. When the means were statistically significant by $\mathrm{F}$ test, these were then subjected to the Tukey test, at $5 \%$ probability. The statistical analysis system SAEG was used (Ribeiro-Júnior, 2001).

\section{Results and Discussion}

The moisture content of seeds from the primary, secondary and tertiary racemes, as well as from mixtures of racemes, varied between $6.0 \%$ and $6.3 \%$ (Table 1). The rainfall lack and the low relative humidity after physiological maturity, as well as during racemes harvesting may have contributed to these low values for moisture content. In this sense, Gonçalves et al. (1981) and Savy-Filho (2005), have reported that castor bean seeds meant to storage should have moisture content between $6.0 \%$ and $10.0 \%$. This manner, the moisture content found within this study for the seeds were below maximum limit of $10.0 \%$, considered ideal for storage. Machado et al. (2010) and Fanan et al. (2009) have also found mean values for castor bean seeds moisture content that were similar to values found in this study for the seeds originating from primary, secondary, and tertiary racemes, soon after harvest.

Coimbra et al. (2007) have emphasized that initial moisture content of seeds is an essential factor for standardization of physiological quality assessment tests to 
be performed and, consequently, for obtaining consistent results. This way, the initial moisture content of seeds has not influenced results obtained on the assessments carried out soon after harvest.

Table 1. Seed moisture content and weight of 1,000 seeds of castor bean, cv. IAC-226, from three different types of racemes and assessed immediately after harvest.

\begin{tabular}{ccccc}
\hline \multirow{2}{*}{ Variable } & \multicolumn{3}{c}{ Type of raceme } \\
\cline { 2 - 4 } & Primary & Secondary & Tertiary & Mixture of racemes \\
\hline Moisture content $(\%)$ & $6.2^{\text {n.s. }}$ & 6.3 & 6.3 & 6.0 \\
Weight of 1,000 seeds $(\mathrm{g})$ & $260.30 \mathrm{a}^{*}$ & $249.24 \mathrm{~b}$ & $238.85 \mathrm{c}$ & $251.25 \mathrm{~b}$ \\
\hline
\end{tabular}

n.s. $=$ Non-significant; $*=$ Means followed by the same letter in line do not statistically differ between each other by Tukey test, at $5 \%$ probability.

The results obtained for seeds from primary racemes statistically differed from the results obtained for the seeds produced on the other types of racemes, presenting the highest value for weight of 1,000 seeds (Table 1). Seeds originating from secondary racemes as well as from mixture of racemes have presented intermediary values for weight of 1,000 seeds. However, the seeds from tertiary racemes have presented lower results (Table 1).

Similar results were found by Machado et al. (2010) that have stressed that the first racemes emitted by plant display seeds with larger size than the racemes afterward emitted. This is possibly due to the fact that the primary raceme is emitted when the motherplant is very well-nourished and with higher accumulation of reserves to form all seeds of the raceme. According to MarcosFilho (2005), these ideal conditions decrease as the next racemes are emitted and new seeds are formed. In addition, Schimann et al. (1978), emphasize that seeds from the primary raceme are of better quality, what is demanded by the own need of subsistence of species, given that the primary racemes are generally better formed and are essential for species maintenance. It is worthy to emphasize that, according to these authors, the seeds of the primary raceme do not present dormancy, as occurs with seeds produced on the secondary and tertiary racemes. Nevertheless, Corrêa et al. (2006) have obtained higher weight for seeds from the secondary racemes in relation to the other two types of racemes (primary and tertiary).

Carvalho and Nakagawa (2000) stressed that not all seeds are formed at the same time; this way, seeds that are formed later are usually smaller or less dense, resulting in less vigorous seeds. These authors still emphasize that the first seeds formed, i.e., those seeds of bigger size are very wellnourished during their development, possessing well-formed embryos and with higher amount of reserve substances and, consequently, are more vigorous. However, these ideal conditions are gradually exhausted, when new racemes are emitted and new seeds are formed (Marcos-Filho, 2005). Nevertheless, Silva and Marcos-Filho (1982) demonstrated that the mass and size of soybean seeds have not influenced the results of tests carried out in laboratory or the performance of soybean plants in the field.

Considering that within this study the highest values for weight of 1,000 seeds were obtained with those seeds produced in the primary raceme, it should be emphasized that these results agree with those obtained by Carvalho and Nakagawa (2000). These authors have observed that the values for percentages of germination and vigor of the seeds that were produced in the primary racemes (which are bigger and originated from the first racemes formed) have also shown having the best physiological quality in relation to seeds produced on other types of racemes (secondary or tertiary) (Table 2). In relation to this fact, Popinigis (1985) has commented that, for many plant species, the size of their seeds is an indicative of their physiological quality. Shepetina and Sevast'yanova (1986) emphasized that germination of castor bean seeds is possibly more linked to their density than to their size.

According to Zuchi et al. (2010), it has been observed a large variability on the size of castor bean seeds; what seems to be correlated as much to genotype of plant as to location of racemes on the plant. In this sense, usually it is verified that the later the racemes are emitted on the plant, smaller will be the size of the seeds produced.

By Brazilian standards for production and commercialization of castor bean seeds (Brasil, 2005), the minimum germination percentage should to be $80 \%$ for basic seeds, and $85 \%$ for certified seeds of first and second generations (C1 and $\mathrm{C} 2$ ) and for the non-certified seeds of first and second generation (S1 and S2). Through data on germination percentage presented on Table 2, it can be verified that these levels were surpassed only for the seed originating from primary racemes. For the seeds originating from the mixture of racemes, the value obtained was of $83 \%$, thus fulfilling requirements for commercialization of basic seeds. Nevertheless, the seeds produced in the secondary and tertiary racemes presented values below minimum commercially demanded standard. 
Table 2. Percentage of normal seedlings, abnormal seedling, dead seeds, and hard seeds originating from castor bean seeds, cv. IAC-226, which were produced in three different types of racemes and assessed immediately after harvest by the standard germination test.

\begin{tabular}{ccccc}
\hline \multirow{2}{*}{ Type of raceme } & \multicolumn{4}{c}{ Percentage of seedlings/seeds } \\
\cline { 2 - 5 } & Normal seedlings & Abnormal seedlings & Dead seeds & Hard seeds \\
\hline Primary & $85 \mathrm{~A}^{*}$ & $6 \mathrm{~B} *$ & $0.7 \mathrm{~A}^{*}$ & $8 \mathrm{~B}^{*}$ \\
Secondary & $56 \mathrm{~B}$ & $2 \mathrm{C}$ & $0.3 \mathrm{~A}$ & $40 \mathrm{~A}$ \\
Tertiary & $53 \mathrm{~B}$ & $3 \mathrm{C}$ & $0.1 \mathrm{~A}$ & $44 \mathrm{~A}$ \\
\hline Mixture of racemes & $83 \mathrm{~A}$ & $14 \mathrm{~A}$ & $0.7 \mathrm{~A}$ & $03 \mathrm{C}$ \\
\hline
\end{tabular}

* Means followed by same letter in columns do not statistically differ between each other by Tukey test, at $5 \%$ probability

Results similar to those found in this study were verified by Machado et al. (2010) that observed higher values for germination percentage in seeds originating from the primary raceme, in relation to the other two types of racemes. In an opposite manner, Fanan et al. (2009) have not found statistically significant differences on germination percentage of seeds produced in different raceme types, when these seeds were assessed soon after harvest; emphasizing that the influence of the climatic factors during the harvest have been compatible with results obtained. Such results show that possibly there are differences among castor bean cultivars in relation to seed germination dynamics, when these are produced in different racemes types on the plant.

The percentage of hard seeds found among the seeds originating from primary racemes, as well as among the seeds collected in the mixtures of racemes was $8 \%$ and $3 \%$, respectively (Table 2). However, in the seeds from the secondary and tertiary racemes, these values were $40 \%$ and $44 \%$, respectively; indicating that these high percentages of hard seeds may be linked to seed dormancy. Lago et al. (1979) have stressed that seeds of castor bean may present dormancy, whose intensity and persistence depend chiefly of cultivar, as well as of maturation stage of seeds at harvest moment, and that this dormancy is more accentuated in seeds produced at tertiary racemes. Nevertheless, Souza et al. (2009) have stressed that seed dormancy has been little detected in the commercial lots of castor bean seeds by them assessed.

By germination test, it can be noticed that values observed for percentage of abnormal seedling were higher for seeds produced in racemes that were harvested together after 178 days (mixture of racemes), as compared to values obtained for the seeds produced in primary, secondary, and tertiary racemes (Table 2). Possibly, permanence in field of seeds produced in these types of racemes, and mainly for those seeds produced in racemes secondary, after reaching ideal harvest point, has contributed for their deterioration. In this sense, it is essentially important to define the ideal harvesting moment; since it is well known that delays on harvesting of physiologically mature seeds, considerably contributes for their deterioration and consequently for significant losses in their physiological quality.

The seed vigor was little influenced by type of racemes in which these seeds were produced (Table 3). There was some statistically significant differences among values obtained for the seeds produced in racemes located in different positions on the plant. The values considered as indicators of vigor that have been found for the seeds produced in primary racemes and in the mixture of racemes, did not differ statistically between each other and were higher than the values obtained for seed produced in the racemes secondary and tertiary; which in their turn did not statistically differ between each other (Table 3). Nevertheless, for the seedling length variable, no significant effect of raceme types has been detected on vigor of the seeds produced.

The values of first count of germination were $73 \%$ and $61 \%$, respectively for the seeds produced in primary racemes or in mixture of racemes (Table 3 ). For the seeds produced in the racemes secondary and tertiary, the values were also lower as compared to values obtained for the seeds obtained in the other two types of racemes (primary and mixture of racemes). Likewise, Machado et al. (2010) have not observed effect of position of racemes on the plants of castor bean over seed physiological quality, when these seeds were assessed by test of first count of germination, carried out soon after harvest.

As discussed previously, the low values obtained for the vigor indicators, especially for seeds originating from the racemes secondary and tertiary may also be linked to occurrence of dormancy on seeds. For Fanan et al. (2009), the dormancy of freshly-harvested seeds may interfere on vigor assessment, not by impeding germination process, but by making it slower.

It is important to emphasize that use of castor bean seeds with high percentage of dormancy leads to flaws on germination and to slow and uneven growth of plants, thus allowing an inadequate distribution of plants in field, besides causing difficulties on controlling weeds and unevenness on maturation; this way, making harvesting procedure more difficult and less efficient (Lago et al., 1979). 
Table 3. Means obtained for variables: first count of germination (FC); seedling emergence (SE); emergence speed index (ESI); seedling dry matter (DM) and length (SL) of castor bean seeds, cv. IAC-226, produced in three different types of racemes and assessed immediately after harvest.

\begin{tabular}{crrrr}
\hline \multirow{2}{*}{ Variable } & \multicolumn{3}{c}{ Type of raceme } \\
\cline { 2 - 5 } & Primary & Secondary & Tertiary & Mixture of racemes \\
\hline FC (\%) & $73.00 \mathrm{a}^{*}$ & $35.00 \mathrm{~b}$ & $31.00 \mathrm{~b}$ & $61.00 \mathrm{a}$ \\
SE (\%) & $40.00 \mathrm{a}$ & $19.00 \mathrm{~b}$ & $14.00 \mathrm{~b}$ & $52.00 \mathrm{a}$ \\
ESI & $3.56 \mathrm{a}$ & $1.68 \mathrm{~b}$ & $1.28 \mathrm{~b}$ & $4.32 \mathrm{a}$ \\
DM (mg.seedling & $2.87 \mathrm{a}$ \\
SL (cm.seedling & $2.19 \mathrm{a}$ & $1.01 \mathrm{~b}$ & $0.83 \mathrm{~b}$ & $18.85 \mathrm{a}$ \\
\hline
\end{tabular}

*Means followed by same letter in the line of each variable do not statistically differ between each other by Tukey test, at $5 \%$ probability.

\section{Conclusions}

Castor bean seeds produced in the primary racemes of the plant have higher weight and vigor as compared to seeds produced on other types of racemes.

The castor bean seeds originating from secondary and tertiary racemes show post-harvest dormancy; and such characteristic is more accentuated on the seeds from tertiary racemes.

\section{Acknowledgements}

To CAPES by the grant of scholarship to first author; to EPAMIG - Unidade Regional Norte de Minas by the support in the laboratory analyses; and to UNIMONTES by provide the area to carry out the field experiment.

\section{References}

BRASIL. Diário Oficial da União. Padrões para produção e comercialização de sementes de mamona. Brasília, DF, n²43, 2005. Seção 1, p.21-22.

BRASIL. Ministério da Agricultura, Pecuária e Abastecimento. Regras para análise de sementes. Ministérios da Agricultura, Pecuária e Abastecimento. Secretaria da Defesa Agropecuária. Brasília: MAPA/ACS, 2009. 395p. http://www.agricultura.gov.br/arq_editor/file/laborat $\% \mathrm{c} 3 \% \mathrm{~b} 3$ rio/sementes/ regras\%20para\%20analise $\% 20 \mathrm{de} \% 20$ sementes.pdf.

CARVALHO, N.M.; NAKAGAWA, J. Sementes: ciência, tecnologia e produção. $4^{\mathrm{a} e d .}$ Jaboticabal: FUNEP, 2000. 588p.

COIMBRA, R.A.; TOMAZ, C.A.; MARTINS, C.C.; NAKAGAWA, J. Teste de germinação com acondicionamento dos rolos de papel em sacos plásticos. Revista Brasileira de Sementes, v.29, n.1, p.92-97, 2007. http://www.scielo. br/scielo.php?pid=S0101-31222007000100013\&script=sci_abstract\&tlng=pt

CORRÊA, M.L.P.; TÁVORA, F.J.A.F.; PITOMBEIRA, J.B. Comportamento de cultivares de mamona em sistemas de cultivo isolados e consorciados com caupi e sorgo granífero. Revista Ciência Agronômica, v.37, n.2, p.200-207, 2006. http://www.ccarevista.ufc.br/seer/index.php/ccarevista/article/view/201

FANAN, S.; MEDINA, P.F.; CAMARGO, M.B.P.; RAMOS, N.P. Influência da colheita e do armazenamento na qualidade fisiológica de sementes de mamona. Revista Brasileira de Sementes, v.25, n.1, p.76-86, 2009. http://www. scielo.br/scielo.php?script=sci_arttext\&pid=S0101-31222009000100017
FREITAS, S.M.; FREDO, C.E. Biodiesel à base de óleo de mamona: algumas considerações. Informações Econômicas, v.35, n.1, p.37-42, 2005. http:// www.iea.sp.gov.br/out/LerTexto.php?codTexto=1663

GONÇALVES, N.P.; FARIA, M.A.V.R.; SATURNINO, H.M.; PACHECO, D.D. Cultura da mamoneira. Informe Agropecuário, v.26, n.229, p.28-32, 2005.

GONÇALVES, N.P.; BENDEZÙ, J.M.; LIMA, C.A.S. Colheita e armazenamento da mamona. Informe Agropecuário, v.82, n.7, p.44-45, 1981.

KOEPPEN, W. Climatologia. Trad. Pedro R.H. Perez. Buenos Aires, Grafica Panamericana, 1948. 478p.

LAGO, A.A.; ZINK, E.; RAZERA, L.F.; BANZATTO, N.V.; SAVY FILHO, A. Dormência em sementes de três cultivares de mamona. Bragantia, v.38, p.41- 44, 1979. http://www.scielo.br/pdf/brag/v38n1/33.pdf

MACHADO, C.G.; MARTINS, C.C.; CRUZ, S.C.S.; NAKAGAWA, J.; PEREIRA, F.R.S. Posição do racemo e do fruto na qualidade fisiológica de sementes de mamona durante o armazenamento. Semina: Ciências Agrárias, v.31, n.2, p.301-312, 2010. http://www.uel.br/revistas/uel/index.php/semagrarias/ article/view/5293

MAGUIRE, J.D. Speed of germination-aid in selection and evaluation for seedling emergence and vigor. Crop Science, v.2, n.1, p.176-177, 1962.

MARCOS-FILHO, J. Deterioração de sementes. In: MARCOS FILHO, J. (Ed.). Fisiologia de sementes de plantas cultivadas. Piracicaba: FEALQ, 2005. p.291-348.

MAZZANI, B. Euforbiáceas oleaginosas. Tártago. In: MAZZANI, B. (Ed.) Cultivo y mejoramiento de plantas oleaginosas. Caracas: Fondo Nacional de Investigaciones Agropecuarias, 1983. p.277-360.

POPINIGIS, F. Fisiologia da semente. Brasília, DF: AGIPLAN, 1985. 289p. RIBEIRO JUNIOR, J.I. Análises estatísticas no Saeg. Viçosa: UFV, 2001. 301p. SAVY FILHO, A. Mamona: tecnologia agrícola. Campinas: EMOPI, 2005. 105p.

SHEPETINA, F.A.; SEVAST'YANOVA, L.B. Seed technology. In: MOSCKIM, V.A. Castor. New Delhi: Amerind, 1986. p.175-178.

SCHIMANN, W.; SAVY-FILHO, A.; BANZATTO, N.V. Produção de sementes de mamona. Campinas: Coordenadoria de Assistência Técnica Integral, 1978. 19p. (Boletim Técnico, 131).

SILVA, W.R.; MARCOS-FILHO, J. Influência do peso e do tamanho das sementes de milho sobre o desempenho no campo. Pesquisa Agropecuária Brasileira, v.17, n.5, p.1743- 1750, 1982. 
SOUZA, L.A.; CARVALHO, M.L.C.; KATAOKA, V.Y.; OLIVEIRA, J.A. Teste de condutividade elétrica para avaliação da qualidade fisiológica de sementes de mamona. Revista Brasileira de Sementes, v.31, n.1, p.60-067, 2009. www.scielo.br/pdf/rbs/v31n1/a07v31n1.pdf
ZUCHI, J.; PANOZZO, L.E.; HEBERLE, E.; DIAS, D.C.F.S. Qualidade fisiológica de sementes de mamona classificadas por tamanho. Revista Brasileira de Sementes, v.32, n.3, p.177-183, 2010. http://www.scielo.br/ scielo.php?pid=S0101-31222010000300020\&script=sci_arttext 